Jurnal Indonesia Sosial Teknologi: p-ISSN: 2723 - 6609

e-ISSN : 2745-5254

Vol. 2, No. 10 Oktober 2021

\title{
PENGARUH ELEMEN PEMASARAN MEDIA SOSIAL TERHADAP KETERLIBATAN KONSUMEN PADA MEREK, KESADARAN MEREK DAN CITRA MEREK
}

\section{Hendayana Panca Nugraha}

Jurusan Magiter Manajemen, Fakultas Binis dan Ekonomika, Universitas Islam Indonesia Yogyakarta

Email : hendapanca7171@gmail.com

\begin{abstract}
Abstrak
Pemasaran media sosial dianggap sebagai kontributor yang kuat dalam membangun pengetahuan merek dan menguntungkan di benak konsumen dan telah diketahui bahwasanya semakin banyak studi empiris telah meneliti teori dan implikasi praktis dari penerapan pemasaran media sosial untuk membangun merek. Namun, pengaruh berbagai elemen pemasaran media sosial pada keterlibatan konsumen pada merek dan pengetahuan merek masih belum cukup jelas, oleh karena itu kondisi membutuhkan penyelidikan teoretis dan empiris lebih lanjut. Dengan melakukan tinjauan literatur yang relevan secara kritis untuk mengidentifikasi kesenjangan penelitian, penelitian ini menyelidiki pengaruh elemen-elemen dari aktivitas pemasaran media sosial, diantaranya entertainment, customisation, interaction, electronic word of mouth serta trendiness pada keterlibatan konsumen pada merek dan pengetahuan tentang merek. Penelitian ini dilakukan dengan pendekatan yang bersifat kuantitatif dan diujikan kepada 300 pengguna media sosial yang menggunakan sepeda Polygon di Indonesia. Adapun temuan penelitian ini mengungkapkan bahwa elemen pemasaran media sosial berperan cukup besar dalam membangun keterlibatan konsumen pada merek dan pengetahuan merek. Studi ini menemukan bahwa entertainment, customitation, interaction, eWOM, dan trendiness merupakan faktor pendorong dalam memperkuat keterlibatan konsmen pada merek, yang kemudian mendorong kesadaran merek dan citra merek. Oleh karena itu, semua elemen-elemen pemasaran media sosial tersebut harus dianggap sebagai cara untuk meningkatkan proses kognitif, afeksi dan aktivasi konsumen terhadap merek.
\end{abstract}

Kata Kunci: Elemen Pemasaran Media Sosial; Keterlibatan Konsumen pada Merek; Kesadaran Merek; dan Citra Merek.

\section{Abstract}

Social media marketing is considered a strong contributor in building brand knowledge and is profitable in the minds of consumers and it is recognized that a growing number of empirical studies have examined the theory and practical implications of applying social media marketing to brand building. However, the influence of various elements of social media marketing on consumer engagement on brands and brand knowledge is still not clear enough, therefore the condition 
requires further theoretical and empirical investigation. By conducting a critical review of relevant literature to identify research gaps, this study investigates the influence of elements of social media marketing activities, including entertainment, customization, interaction, electronic word of mouth and trendiness on consumer engagement with brands and brand knowledge. This research was conducted with a quantitative approach and tested on 300 social media users who use Polygon bicycles in Indonesia. The findings of this study reveal that the elements of social media marketing play a significant role in building consumer involvement in brands and brand knowledge. This study found that entertainment, customization, interaction, eWOM, and trendiness were the driving factors in strengthening consumer involvement in the brand, which in turn boosted brand awareness and brand image. Therefore, all these elements of social media marketing should be considered as a way to improve the cognitive processes, affection and activation of consumers towards the brand.

Keyword: Elements of Social Media Marketing; Consumer Engagement in Brands; Brand Awareness; and Brand Image.

\section{Pendahuluan}

Dalam tiga dekade terakhir, arus penelitian yang kuat telah muncul menyoroti sifat dan dinamika yang berkaitan dengan hubungan konsumen atau merek tertentu. Dalam fenomena yang muncul ini, keterlibatan konsumen pada merek mencerminkan tingkat minat konsumen dan relevansi pribadi dari suatu merek telah mendapatkan perhatian yang signifikan. Namun, terlepas dari wawasan penting yang diperoleh dari penelitian terkait keterlibatan tersebut, penekanan ilmiah baru-baru ini bergeser ke konsep dan perspektif teoritis, yang menjelaskan atau memprediksi dinamika yang mencirikan hubungan konsumen atau merek interaktif secara lebih eksplisit, termasuk dalam pengaturan media sosial tertentu.

Terkait erat dengan keterlibatan konsumen pada merek, pemasaran media sosial melibatkan penerapan dan pengembangan terkait strategi pemasaran dengan pemanfaatan platform media sosial guna mengkomunikasikan informasi terkait merek serta mengelola hubungan dengan pelanggan (Schultz \& Peltier, 2013); (Solem \& Pedersen, 2016); (Thoring, 2011). Pada dasarnya, pemasaran media sosial memainkan peran yang cukup besar dalam mempengaruhi persepsi konsumen terhadap merek (Langaro, Rita, \& de Fátima Salgueiro, 2018), dan konsumen semakin mencari informasi tentang produk dan merek menggunakan saluran media sosial. Oleh karena itu, ada pandangan bahwa pemasaran media sosial memperkuat pengetahuan merek konsumen lebih dari komunikasi pemasaran tradisional (Bruhn, Schoenmueller, \& Schäfer, 2012) (Frank \& Watchravesringkan, 2016).

Dalam konteks yang lebih luas, konsep keterlibatan konsumen yang secara lebih eksplisit menjelaskan dinamika interaksi konsumen terkait merek (Brodie, Hollebeek, Jurić, \& Ilić, 2011), telah menjadi daya tarik dalam berbagai literatur, sehingga sesuai 
dengan perspektif teoritis yang lebih luas dari teori budaya konsumen, dan hubungan pemasaran (Vivek, Beatty, \& Morgan, 2012).

Keterlibatan konsumen pada merek adalah konsep terbaru dalam literatur pemasaran yang memperluas domain hubungan pemasaran (Vivek et al., 2012), yang saat ini ditekankan sebagai pendorong fundamental dari kedua proses pengambilan keputusan konsumen serta ekuitas merek (Schultz \& Block, 2011), yang umumnya dianggap oleh pemasar sebagai prioritas dalam strategi branding (Linda Hollebeek, 2011). Keterlibatan konsumen pada merek merupakan sebuah dimensi kognitif, emosional serta perilaku dari konstruksi multidimensi (Brodie et al., 2011); (Dessart, Veloutsou, \& Morgan-Thomas, 2016); (Dwivedi, 2015); (Linda Hollebeek, 2011); (Vivek et al., 2012).

Minat penelitian muncul dari pengakuan akan pentingnya keterlibatan konsumen pada merek untuk strategi pemasaran, yang mencakup penciptaan dan peningkatan hubungan antara konsumen dan merek (Brodie, Ilic, Juric, \& Hollebeek, 2013); (Chiang, Wei, Parker, \& Davey, 2017); (Hepola, Karjaluoto, \& Hintikka, 2017). Dilaporkan, selama lima tahun ke depan, lebih dari 80 persen pemasar akan berusaha melibatkan konsumen dengan membangun hubungan dengan mereka, berdasarkan ekspektasi bahwa konsumen yang terlibat cenderung mengunjungi 40 persen lebih banyak per tahun, menambah 20 persen dalam hal profitabilitas (Pansari \& Kumar, 2017).

Diakui sebagai area prioritas untuk riset pemasaran, keterlibatan konsumen pada merek adalah konstruksi yang berpengaruh dalam membangun atau membentuk kecintaan merek, kepuasan pelanggan dan loyalitas merek, meningkatkan efektivitas periklanan dan kinerja bisnis secara keseluruhan (Kumar \& Pansari, 2016). Dengan demikian, pemasar berusaha untuk memperdalam pemahaman mereka tentang bagaimana keterlibatan konsumen pada merek dibentuk, dipelihara, dan dipertahankan (Schultz \& Peltier, 2013).

Oleh karena itu, ada seruan untuk memperkuat kerangka teoritis yang mendasari keterlibatan konsumen pada merek dengan bukti empiris (Linda D. Hollebeek, Glynn, \& Brodie, 2014), terutama mengenai apa yang menyangkut anteseden dan konsekuensinya (Pansari \& Kumar, 2017). Dapat dikatakan bahwasanya terdapat kebutuhan untuk penelitian empiris tentang keterlibatan konsumen pada merek guna meningkatkan pemahaman tentang konstruksi, pendorong dan metode, seperti penggunaan komunikasi pemasaran untuk memperoleh dan mempertahankan konsumen melalui peningkatan hubungan antara konsumen dan merek (Cheung, Pires, \& Rosenberger, 2020).

Dalam literatur terkait manajemen pemasaran, diketahui bahwasanya masalah terkait keterlibatan konsumen telah mendapat banyak pertimbangan substansial dari para ahli pemasaran, secara khusus terkait referensi penelitian yang melibatkan media sosial. Adapun dalam konteks dunia bisnis, keterlibatan konsumen dilibatkan guna mempertahankan perhatian konsumen yang dalam hal ini telah disorot oleh Marketing Science Institute (MSI), sebuah organisasi global berbasis penelitian (MSI, 2016), 
sebagai salah satu perhatian utama dalam penelitian antara periode tahun 2014 sampai 2016.

Masalah tersebut telah disoroti oleh para pakar dan peneliti sebagai pendorong utama proses pengambilan keputusan konsumen karena keterlibatan konsumen dapat menghasilkan kepuasan, loyalitas, kepercayaan, dan komitmen konsumen (Brodie et al., 2013). Disamping itu, hubungan antara penjual dan pembeli dapat dengan mudah diciptakan melalui keterlibatan konsumen. Sebagai ikatan kedua belah pihak, pengalaman konsumen penciptaan nilai untuk keduanya. Hal ini menggambarkan bahwasanya peningkatan aksesibilitas platform media sosial harus dilihat secara positif ketika platform tersebut muncul untuk memfasilitasi keterlibatan konsumen tersebut.

Secara lebih jauh, platform media sosial dapat memberikan peluang bagi para konsumen untuk dapat terhubung dengan pengecer dan pembeli lainnya. Dengan pemanfaatan media sosial, penjual dapat membangun relasi dengan konsumen yang sudah ada ataupun yang baru yang pada akhirnya, komunitas pengguna platform media sosial dapat dibentuk dimana penjual dan pembeli berinteraksi dan berkomunikasi satu dengan yang lain dalam hal masalah yang dihadapi dan solusi untuk menyelesaikan masalah tersebut. Studi saat ini menjawab panggilan untuk penelitian empiris lebih pada keterlibatan konsumen (Linda D. Hollebeek et al., 2014).

Sejak kemunculannya, media sosial terutama situs jejaring sosial, telah memperkenalkan cara interaksi dan keterlibatan baru yang radikal antara konsumen dan merek. Konsumen semakin banyak menggunakan media sosial tidak hanya untuk meneliti produk dan layanan, tetapi juga untuk terlibat dengan perusahaan tempat mereka membeli, serta konsumen lain yang mungkin memiliki wawasan berharga tentang perusahaan tersebut. Merek dapat menjangkau konsumen menggunakan komunikasi mereka sendiri dan komunikasi konsumen. Dalam lingkungan baru ini, mencapai keterlibatan konsumen sangat penting bagi merek untuk melawan peningkatan kekebalan konsumen dari dan skeptisisme terhadap media komersial tradisional.

Selain itu, bentuk keterlibatan baru di media sosial ini membuka banyak peluang baru bagi merek untuk mengekstrak nilai dari konsumen yang ada dan calon konsumen. Mereka sekarang dapat menerima umpan balik dan saran dengan lebih mudah dari konsumen mereka melalui situs jejaring sosial ini, memungkinkan mereka untuk menanggapi konsumen mereka, meningkatkan penawaran mereka, menangani masalah dan memberikan layanan yang lebih baik. Meskipun bentuk keterlibatan baru ini mencakup berbagai aktivitas, perilaku khusus seperti menyukai dan mengomentari halaman media sosial merek telah menjadi sangat populer di kalangan konsumen sehingga sekarang digunakan sebagai ukuran keterlibatan konsumen di media sosial (Gummerus, Liljander, Weman, \& Pihlström, 2012).

Dilaporkan bahwasanya 74 persen konsumen online menggunakan platform media sosial, dan lebih dari 50 persen platform media sosial memperoleh informasi terkait merek dengan mengikuti halaman merek (Ismail, 2017). Laporan statistik terbaru menilai tingkat penetrasi media sosial global pada 42 persen, dengan lebih dari 3 miliar 
pengguna aktif bulanan. Penggunaan ini membantu menjelaskan mengapa lebih dari 90 persen bisnis dilaporkan menyertakan komunikasi media sosial dalam strategi pemasaran mereka, dengan menggunakan Facebook, Instagram, Twitter dan YouTube untuk mengkomunikasikan informasi merek kepada konsumen (Stelzner, 2014). Bisnis menggunakan platform media sosial untuk mengkomunikasikan informasi terkait merek, seperti berbagi pembaruan dan menghasilkan umpan balik, serta untuk mendapatkan informasi tentang preferensi konsumen dan untuk mengelola hubungan dengan pelanggan, yang semuanya memfasilitasi pembangunan keterlibatan konsumen dan merek yang kuat (Thoring, 2011).

Para pemasar memahami keunggulan pemasaran media sosial relatif terhadap periklanan tradisional dalam berkomunikasi dengan pelanggan dan dalam aktivitas membangun merek (Abzari, Ghassemi, \& Vosta, 2014), (Knoll, 2016), (Weinberg, de Ruyter, Dellarocas, Buck, \& Keeling, 2013). Namun, sebagian besar penelitian pemasaran media sosial sampai saat ini fokus pada daya tarik konten yang dibuat pengguna, pada analisis konten, pada strategi kreatif (Ashley \& Tuten, 2015) dan pada perilaku konsumen sebagai bagian dari komunitas merek media sosial. Oleh karena itu, pemasaran media sosial masih dianggap sebagai alat pemasaran yang relatif baru dan pemahaman tentang bagaimana hal itu memengaruhi keterlibatan konsumen pada merek masih terbatas (Ashley \& Tuten, 2015).

Tantangan berkelanjutan yang dihadapi oleh pemasar dalam membuat dan menerapkan strategi pemasaran media sosial yang menarik dan berharga bagi konsumen memerlukan studi lebih lanjut tentang konten pemasaran media sosial dan pengalaman konsumen (Schultz \& Peltier, 2013). Sebuah ilustrasi menjadi seruan saat ini untuk penelitian empiris yang memeriksa strategi dan konten yang mengarah pada keterlibatan konsumen pada merek, bersama dengan hasil keterlibatan konsumen pada merek. Salah satu hasil khusus yang membangkitkan minat ilmiah adalah pengetahuan merek, yang dianggap mendorong kesuksesan bisnis dengan mempengaruhi loyalitas merek, niat membeli, dan keunggulan kompetitif.

Adapun pengetahuan merek konsumen berkaitan dengan representasi kognitif merek. Pengetahuan merek konsumen dapat didefinisikan dalam pengertian pribadi tentang suatu merek yang disimpan dalam memori konsumen, yaitu semua informasi terkait merek yang deskriptif dan evaluatif. Para peneliti telah mempelajari pengetahuan merek konsumen selama beberapa dekade, dengan area yang berbeda menerima penekanan lebih besar tergantung pada paradigma penelitian dominan dan dorongan waktu.

Pemasaran media sosial dianggap sebagai kontributor yang kuat dalam membangun pengetahuan merek dan menguntungkan di benak konsumen (Ashley \&

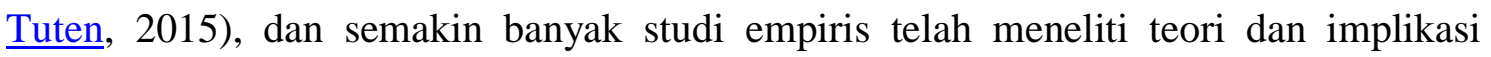
praktis dari penerapan pemasaran media sosial untuk membangun merek. Namun, pengaruh berbagai elemen pemasaran media sosial pada keterlibatan konsumen pada merek dan pengetahuan merek masih belum jelas, oleh karena itu membutuhkan penyelidikan teoretis dan empiris lebih lanjut. 
Dengan melakukan tinjauan literatur yang relevan secara kritis untuk mengidentifikasi kesenjangan penelitian, penelitian ini menyelidiki pengaruh elemenelemen dari aktivitas pemasaran media sosial, diantaranya entertainment, customisation, interaction, electronic word of mouth serta trendiness pada keterlibatan konsumen pada merek dan pengetahuan tentang merek.

Oleh karena itu, pertanyaan utama dalam penelitian ini yang akan di jawab yaitu sebagai berikut: bagaimanakah hubungan antara elemen pemasaran media sosial pada keterlibatan konsumen pada merek, citra merek dan kesadaran konsumen tentang merek. Adapun objek penelitian ini difokuskan pada pengguna media sosial yang menggunakan sepeda Polygon di Indonesia dimana sebelumnya belum pernah dilakukan.

\section{Metode Penelitian}

Populasi yang digunakan dalam penelitian ini adalah seluruh pengguna media sosial yang menggunakan sepeda Polygon di Indonesia. Teknik pengambilan sampel Non Probability Sampling yang digunakan dalam penelitian ini adalah dengan metode sampling aksidental (accidental sampling). Aksidental sampling (convenience sampling) adalah prosedur sampling yang memilih sampel dari orang atau unit yang paling mudah dijumpai atau diakses. Adapun dalam penelitian ini peneliti mengambil sampel sebanyak 300 pengguna media sosial yang menggunakan sepeda Polygon di Indonesia. Adapun pernyataan yang diajukan berupa kuesioner yang diajukan melalui computer (Computer-delivery survey) dengan menggunakan internet (google form).

Skala pengukuran yang digunakan dalam penelitian ini adalah skala Likert yang mempunya gradasi dari sangat tidak setuju dengan skor 1, tidak setuju dengan skor 2, agak tidak setuju dengan skor 3, agak setuju dengan skor 4, setuju dengan skor 5, dan sangat setuju dengan skor 6. Alat analisis yang digunakan dalam penelitian ini adalah analisis deskriptif dengan metode analisis Structural Equation Model (SEM). Adapun kerangka konsep penelitian yang dilakukan adalah sebagai berikut:

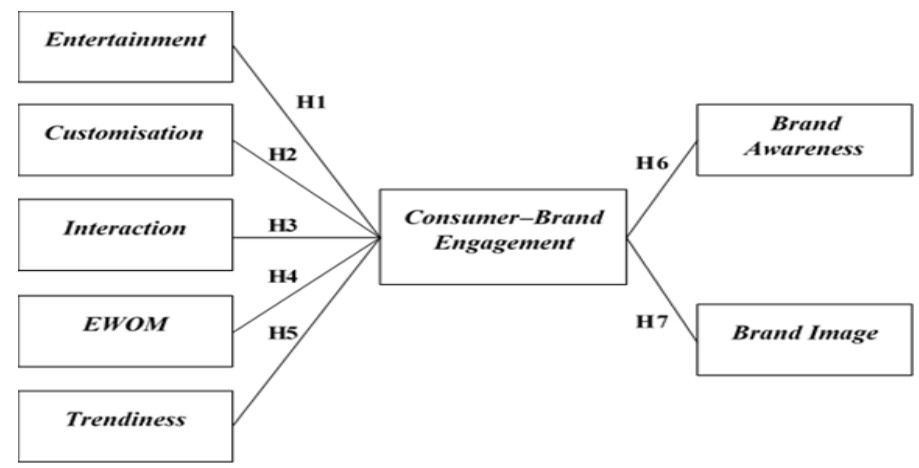

Gambar 1. Model Penelitian 


\section{Hasil dan Pembahasan}

Berdasarkan analisis statistik dengan menggunakan program AMOS 22, diketahui bahwasanya hasil uji hipotesis yang merupakan uji hubungan kausalitas dari masing masing variabel penelitian akan disajikan pada tabel berikut ini:

Tabel 1. Pengaruh Antar Variabel

\begin{tabular}{lcrcccc}
\hline \multicolumn{2}{c}{ Pengaruh Antar Variabel } & Standar Estimate & S.E. & C.R. & P & Ket \\
\hline Engagement & <--- Entertaiment & 0.236 & 0.087 & 3.675 & 0.000 & Diterima \\
\hline Engagement & <--- Customitation & 0.188 & 0.065 & 3.100 & 0.002 & Diterima \\
\hline Engagement & <--- Interaction & 0.252 & 0.065 & 4.471 & 0.000 & Diterima \\
\hline Engagement & <--- EWOM & 0.320 & 0.065 & 4.628 & 0.000 & Diterima \\
\hline Engagement & $<---$ Trendiness & 0.170 & 0.052 & 3.379 & 0.000 & Diterima \\
\hline Brand Image & $<---$ Engagement & 0.264 & 0.076 & 3.711 & 0.000 & Diterima \\
\hline Brand Awareness $<---$ Engagement & 0.206 & 0.066 & 2.864 & 0.004 & Diterima \\
\hline
\end{tabular}

Sumber : Olah data tahun, 2021

Pemasaran media sosial dianggap sebagai kontributor kuat untuk membentuk pengetahuan merek yang kuat serta dapat menguntungkan di benak para konsumen (Ashley \& Tuten, 2015), dan semakin banyak studi empiris telah meneliti teori dan implikasi praktis dari penerapan pemasaran media sosial untuk membangun merek. Namun, pengaruh berbagai elemen pemasaran media sosial pada keterlibatan konsumen pada merek dan pengetahuan merek masih belum jelas, oleh karena itu membutuhkan penyelidikan teoritis dan empiris lebih lanjut.

Hasil penelitian ini sejalan dengan penelitian sebelumnya tentang elemen pemasaran media sosial, bahwasanya komunikasi merek dengan elemen entertainment dianggap mengasyikkan dan menyenangkan (Ashley \& Tuten, 2015) serta dapat mendorong konsumen secara lebih besar untuk mengerahkan upaya kognitif mereka dalam memahami lebih jauh tentang merek. Penelitian ini juga sejalan dengan menyatakan bahwasanya entertainment memiliki pengaruh pada keterlibtan konsumen pada produk. Adapun terkait kesamaan hasil penelitian diatas, terdapat penelitian lain yang dilakukan yang mengemukakan bahwasanya terdapat hubungan yang tidak signifikan antara entertainment dan keterlibatan konsumen pada produk.

Hasil penelitian selanjutnya terkait hubungan variabel Customization dengan keterlibatan konsumen, hasil penelitian ini sejalan dengan penelitian sebelumnya yang menyatakan bahwa pemasaran media sosial yang dikustomisai dapat mempengaruhi pembangunan pengalaman kognitif dan afektif dalam pikiran konsumen yang mendorong aktivasi. Oleh karena itu dalam proses pengambilan keputusan, konsumen akan lebih bersedia untuk mempertimbangkan merek tertentu sebagai pilihan utama mereka (Harrigan et al., 2018). Hasil penelitian ini juga mendukung temuan lain yang mengemukakan bahwa media sosial yang dikustomisasi mampu membangun kepercayaan konsumen pada merek serta mampu meningkatkan atau memperkuat nilai yang dirasakan dari halaman merek. Sedangkan penelitian yang dilakukan (Cheung et 
al., 2020) mengemukakan bahwasanya terdapat hubungan yang tidak signifikan antara kustomisasi dan keterlibatan konsumen pada produk.

Temuan terkait hubungan variabel Interaction dengan keterlibatan konsumen pada penelitian ini mendukung hasil penelitian yang dilakukan (Cheung et al., 2020) yang mengemukakan adanya hubungan yang signifikan antara Interaction dan keterlibatan konsumen pada produk. Diketahui bahwasanya interaksi antara konsumen dan merek dapat meningkatkan merek dalam proses pengembangan produk baru, dimana konsumen secara aktif melakukan aktivitas berbagi ide serta memberikan umpan balik atau respon terkait produk baru. Aktifitas berbagi tersebut, dapat meningkatkan kepuasan pelanggan serta mampu memperkuat niat beli dan kepercayaan merek. Selanjutnya, meningkatnya kepuasan pelanggan dapat diubah menjadi pengembangan dan aktivasi terkait keterlibatan konsumen pada produk.

Kemudian hasil temuan terkait hubungan variabel EWOM dan Trendiness ditmukan memiliki pengaruh pada keterlibtan konsumen. Hasil penelitian ini mendukung penelitian yang dilakukan (Cheung et al., 2020) yang mengungkapkan bahwa Interaction, electronic word of mouth, dan trendiness adalah elemen kunci yang secara langsung mempengaruhi keterlibatan konsumen pada merek. Selanjutnya hasil penelitian ini menumukan bahwasanya keterlibatan Konsumen memiliki pengaruh yang positif terhadap Kesadaran Merek dan Citra merek. Hasil tersebut didukung dengan hasil penelitian sebelumnya dimana (Cheung et al., 2020) dalam penelitiannya mengungkapkan bahwa keterlibatan konsumen pada merek memiliki dampak yang kuat dan positif terhadap Kesadaran Merek dan Citra Merek yang secara langsung menegaskan pentingnya keterlibatan konsumen dalam membangun pengetahuan tentang merek. Hasil penelitian ini juga sejalan dengan temuan lain yang mengungkapkan bahwa keterlibatan konsumen pada merek memiliki dampak yang kuat dan positif pada kesadaran merek dan citra merek, menegaskan pentingnya keterlibatan konsumen pada merek dalam membangun pengetahuan merek (Keller, 2013).

Secara umum, temuan penelitian ini mengungkapkan bahwa elemen pemasaran media sosial berperan cukup besar dalam membangun keterlibatan konsumen pada merek dan pengetahuan merek. Studi ini menemukan bahwa entertaiment, customitation, interaction, eWOM, dan Trendiness merupakan faktor pendorong dalam memperkuat keterlibatan konsmen pada merek, yang kemudian mendorong kesadaran merek dan citra merek, sebagian ditegaskan pula oleh temuan literatur sebelumnya (seperti Choi et al., 2016; Kim dan Ko, 2010; Kim dan Lee, 2019). Oleh karena itu, semua elemenelemen pemasaran media sosial tersebut harus dianggap sebagai cara untuk meningkatkan proses kognitif, afeksi dan aktivasi konsumen terhadap merek.

\section{Kesimpulan}

Penelitian ini bertujuan untuk menguji pengaruh elemen pemasaran media sosial terhadap keterlibatan konsumen pada merek, kesadaran merek dan citra merek. Secara umum, temuan penelitian ini mengungkapkan bahwa elemen pemasaran media sosial berperan cukup besar dalam membangun keterlibatan konsumen pada merek dan 
pengetahuan merek. Studi ini menemukan bahwa entertaiment, customitation, interaction, eWOM, dan trendiness merupakan faktor pendorong dalam memperkuat keterlibatan konsmen pada merek, yang kemudian mendorong kesadaran merek dan citra merek. Oleh karena itu, semua elemen-elemen pemasaran media sosial tersebut harus dianggap sebagai cara untuk meningkatkan proses kognitif, afeksi dan aktivasi konsumen terhadap merek.

Mempertimbangkan beberapa keterbatasan yang terdapat dalam penelitian ini, penulis berharap bahwa penelitian ini dapat lebih ditingkatkan untuk memberikan hasil yang lebih baik dan lebih akurat. Diketahui bahwasanya penelitian ini bersifat CrossSectional-Study, dimana hasil penelitian ini tidak dapat menggambarkan dinamikan atau perubahan aktivitas pemasaran media sosial serta penelitian ini dilakukan hanya fokus pada produk sepeda Polygon.

Oleh karena itu, keterbatasan ini membatasi generalisasi hasil studi ke wilayah geografis yang lebih luas. Mempertimbangkan beberapa keterbatasan yang terdapat dalam penelitian ini, penulis berharap bahwa penelitian ini dapat lebih ditingkatkan untuk memberikan hasil yang lebih baik dan lebih akurat. Keterbatasan ini membatasi generalisasi hasil studi pada objek penelitian yang lebih luas. Maka, penulis merekomendasikan untuk penelitian mendatang agar dapat melakukan penelitian yang diperluas sepeti merek sepeda lain atau varian produk lain seperti mobil, motor dan lain sebagainya. 


\section{Bibliografi}

Abzari, Mehdi, Ghassemi, Reza Abachian, \& Vosta, Leila Nasrolahi. (2014). Analysing the effect of social media on brand attitude and purchase intention: The case of Iran Khodro Company. Procedia-Social and Behavioral Sciences, 143, 822-826. https://doi.org/10.1016/j.sbspro.2014.07.483

Ashley, Christy, \& Tuten, Tracy. (2015). Creative strategies in social media marketing: An exploratory study of branded social content and consumer engagement. Psychology \& Marketing, 32(1), 15-27. https://doi.org/10.1002/mar.20761

Brodie, Roderick J., Hollebeek, Linda D., Jurić, Biljana, \& Ilić, Ana. (2011). Customer engagement: Conceptual domain, fundamental propositions, and implications for research. Journal of Service Research, 14(3), 252-271. https://doi.org/10.1177/1094670511411703

Brodie, Roderick J., Ilic, Ana, Juric, Biljana, \& Hollebeek, Linda. (2013). Consumer engagement in a virtual brand community: An exploratory analysis. Journal of Business Research, 66(1), 105-114. https://doi.org/10.1016/j.jbusres.2011.07.029

Bruhn, Manfred, Schoenmueller, Verena, \& Schäfer, Daniela B. (2012). Are social media replacing traditional media in terms of brand equity creation? Management Research Review. https://doi.org/10.1108/01409171211255948

Cheung, Man Lai, Pires, Guilherme, \& Rosenberger, Philip J. (2020). The influence of perceived social media marketing elements on consumer-brand engagement and brand knowledge. Asia Pacific Journal of Marketing and Logistics. https://doi.org/10.1108/APJML-04-2019-0262

Chiang, Chang Tang, Wei, Chiou Fong, Parker, Kevin R., \& Davey, Bill. (2017). Exploring the drivers of customer engagement behaviours in social network brand communities: towards a customer-learning model. Journal of Marketing Management, 33(17-18), 1443-1464. https://doi.org/10.1080/0267257X.2017.1399922

Dessart, Laurence, Veloutsou, Cleopatra, \& Morgan-Thomas, Anna. (2016). Capturing consumer engagement: duality, dimensionality and measurement. Journal of Marketing Management, 32(5-6), 399-426. https://doi.org/10.1080/0267257X.2015.1130738

Dwivedi, Abhishek. (2015). A higher-order model of consumer brand engagement and its impact on loyalty intentions. Journal of Retailing and Consumer Services, 24, 100-109. https://doi.org/10.1016/j.jretconser.2015.02.007

Frank, Phillip, \& Watchravesringkan, Kittichai Tu. (2016). Exploring antecedents and consequences of young consumers' perceived global brand equity. Journal of Product \& Brand Management. https://doi.org/10.1108/JPBM-01-2015-0786 
Gummerus, Johanna, Liljander, Veronica, Weman, Emil, \& Pihlström, Minna. (2012). Customer engagement in a Facebook brand community. Management Research Review. https://doi.org/10.1108/01409171211256578

Hepola, Janne, Karjaluoto, Heikki, \& Hintikka, Anni. (2017). The effect of sensory brand experience and involvement on brand equity directly and indirectly through consumer brand engagement. Journal of Product \& Brand Management.

Hollebeek, Linda. (2011). Exploring customer brand engagement: definition and themes. Journal of Strategic Marketing, 19(7), 555-573. https://doi.org/10.1080/0965254X.2011.599493

Hollebeek, Linda D., Glynn, Mark S., \& Brodie, Roderick J. (2014). Consumer brand engagement in social media: Conceptualization, scale development and validation. Journal of Interactive Marketing, 28(2), 149-165. https://doi.org/10.1016/j.intmar.2013.12.002

Ismail, Ahmed Rageh. (2017). The influence of perceived social media marketing activities on brand loyalty: The mediation effect of brand and value consciousness. Asia Pacific Journal of Marketing and Logistics, 29(1), 129-144. http://dx.doi.org/10.1108/APJML-10-2015-0154

Knoll, Johannes. (2016). Advertising in social media: a review of empirical evidence. International Journal of Advertising, 35(2), 266-300. https://doi.org/10.1080/02650487.2015.1021898

Kumar, Viswanathan, \& Pansari, Anita. (2016). Competitive advantage through engagement. Journal of Marketing Research, 53(4), 497-514. https://doi.org/10.1509/jmr.15.0044

Langaro, Daniela, Rita, Paulo, \& de Fátima Salgueiro, Maria. (2018). Do social networking sites contribute for building brands? Evaluating the impact of users' participation on brand awareness and brand attitude. Journal of Marketing Communications, 24(2), 146-168 .https://doi.org/10.1080/13527266.2015.1036100

Pansari, Anita, \& Kumar, Vera. (2017). Customer engagement: the construct, antecedents, and consequences. Journal of the Academy of Marketing Science, 45(3), 294-311.

Schultz, Don E., \& Block, Martin P. (2011). Understanding customer brand engagement behaviors in today's interactive marketplace. Micro \& Macro Marketing, 20(2), 227-244.

Schultz, Don E., \& Peltier, James Jimmy. (2013). Social media's slippery slope: challenges, opportunities and future research directions. Journal of Research in Interactive Marketing.

Solem, Birgit Andrine Apenes, \& Pedersen, Per Egil. (2016). The effects of regulatory 
fit on customer brand engagement: an experimental study of service brand activities in social media. Journal of Marketing Management, 32(5-6), 445-468.

Stelzner, M. (2014). Social media marketing industry report how marketers are using social media to grow their businesses.[Online] http://www. socialmediaexaminer. com. SocialMediaMarketingIndustryReport2014. Pdf [Erişildi: 06 Mayls 2019].

Thoring, Anne. (2011). Corporate tweeting: analysing the use of Twitter as a marketing tool by UK trade publishers. Publishing Research Quarterly, 27(2), 141-158.

Vivek, Shiri D., Beatty, Sharon E., \& Morgan, Robert M. (2012). Customer engagement: Exploring customer relationships beyond purchase. Journal of Marketing Theory and Practice, 20(2), 122-146.

Weinberg, Bruce D., de Ruyter, Ko, Dellarocas, Chrysanthos, Buck, Michael, \& Keeling, Debbie Isobel. (2013). Destination social business: Exploring an organization's journey with social media, collaborative community and expressive individuality. Journal of Interactive Marketing, 27(4), 299-310. 